\title{
ENDOCRINE ABNORMALITIES IN PATIENTS WITH CHRONIC KIDNEY DISEASE
}

\section{Piotr Kuczera, Marcin Adamczak, Andrzej Wiecek}

Department of Nephrology, Transplantation and Internal Medicine, Medical University of Silesia, Katowice, Poland

Corresponding Author: Prof. dr hab. med. Andrzej Więcek, FRCP (Edin), FERA, Department of Nephrology, Transplantation and Internal Medicine, Medical University of Silesia, Katowice, Francuska Str. 20/24, 40-027 Katowice, Poland; Tel: +48-322552695, Fax: +48-322553726; E-mail: awiecek@ sum.edu.pl

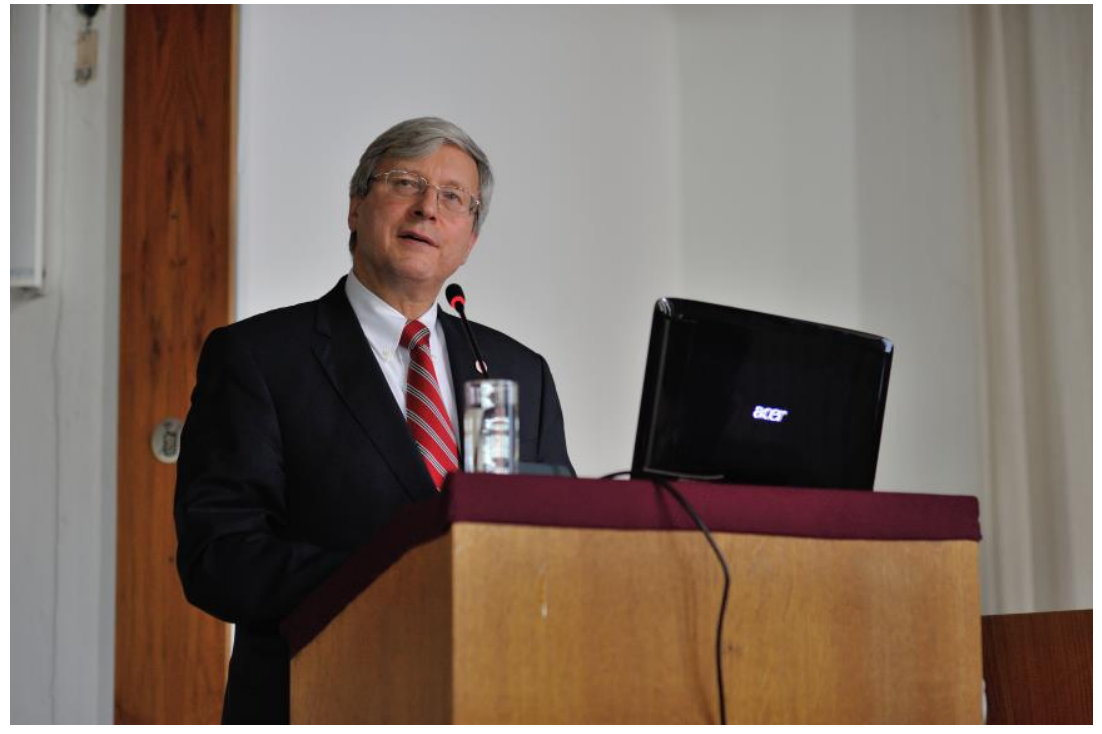

\begin{abstract}
In patients with chronic kidney disease the alterations of the endocrine system may arise from several causes. The kidney is the site of degradation as well as synthesis of many different hormones. Moreover, a number of concomitant pathological conditions such as inflammation, metabolic acidosis and malnutrition may participate in the pathogenesis of endocrine abnormalities in this group of patients. The most pronounced endocrine abnormalities in patients with chronic kidney disease are the deficiencies of: calcitriol, testosterone, insulin-like growth factor and, erythropoietin (EPO). Additionally accumulation of several hormones, such as: prolactin, growth hormone and insulin frequently also occur. The clinical consequences of the abovementioned endocrine abnormalities are among others: anemia, infertility and bone diseases.
\end{abstract}

Key words: Chronic kidney disease, Endocrine abnormalities, Erythropoietin

\section{Introduction}

Endocrine abnormalities in patients with chronic kidney disease (CKD) and in patients receiving renal replacement treatment (RRT) may arise from a number of different causes, which are briefly summarized in Table 1 .
The kidneys are complex organs in which the synthesis and degradation of different hormones takes place. Moreover, several concomitant conditions e.g.: inflammation, metabolic acidosis and malnutrition can participate in the pathogenesis of many alterations of the endocrine system. 
The clinicians nowadays have a possibility to assess plasma concentration of several different hormones, all of which may, or may not be abnormal. However, many of these measurements are of limited value in CKD and RRT patients. Estimation of plasma concentrations of many hormones has been shown not to provide a proper assessment of the hormonal status adequacy (hormone concentrations may be inadequate in the context of the stimulating or suppressing signals, the test can detect inactive hormone isoforms, also the target organs' response may be aggravated or blunted). Therefore it seems necessary to interpret plasma hormone concentrations along with the underlying clinical context (e.g.: parathyroid hormone $(\mathrm{PTH})$ concentration in relation to the ionized calcium concentration, or insulin concentration in relation to glucose concentration).

Table 1

The etiology of selected endocrine abnormalities in chronic kidney disease

\begin{tabular}{ll}
\hline Type of defect & Example \\
\hline $\begin{array}{l}\text { Abnormalities of hormone catabolism } \\
\text { Decreased metabolic clearance }\end{array}$ & Insulin, PTH, leptin, adiponectin, gastrin
\end{tabular}

\section{Abnormalities of hormone production}

Reduced hormone production

in endocrine organs

Reduced hormone production by the kidney

Reactive hypersecretion of hormone to reestablish homeostasis

Inappropriate hypersecretion due to disturbed feedback

Abnormal secretion pattern (pulsatility; circadian rhythm)

\section{Abnormalities of hormone activity}

Increased isoforms with potentially less bioactivity (because of posttranscriptional modifications)

Increased serum hormone binding proteins concentration resulting in the reduced availability of free hormone

Decreased serum hormone binding proteins concentration resulting in the increased availability of free hormone

Changed receptor quantity and/or structure

Altered postreceptor cellular signaling

Altered activation of prohormones testosterone, estrogens

$1,25(\mathrm{OH})_{2} \mathrm{D}_{3}$, erythropoietin

PTH, FGF 23, erythropoietin

ACTH, LH, prolactin

$\mathrm{GH}, \mathrm{LH}$

LH

IGF

leptin

vitamin $\mathrm{D}$ receptor

insulin, GH

proinsulin, thyroxin $\left(\mathrm{T}_{4}\right)$

PTH - parathyroid hormone; FGF 23 - fibroblast growth factor 23; ACTH - adrenocorticotropin; LH - luteinizing hormone; GH - growth hormone; IGF - insulin-like growth factor.

\section{Abnormalities in the secretion of erythropoietin}

In the adults kidneys are responsible of synthesis of approximately 85-90\% of circulating erythropoietin (EPO), while the liver is the source of the remaining $10-15 \%$.

The main stimulus for EPO synthesis in the peritubular cells of the renal cortex is the renal hypoxia, which may be caused by anemia or hypoxemia. Hypoxia stimulates Hypoxia In- ducible Factor (HIF) synthesis, which is responsible for the activation of variety of genes, among others also the EPO gene.

Another factor stimulating the renal EPO production is angiotensin II. Conversely, proteins typically linked with inflammation (e.g. interleukin-1 - [IL-1] and tumor necrosis factor- $\alpha-$ $[\mathrm{TNF}-\alpha]$ ) inhibit EPO secretion. Recently it has been shown that also infectious factors such as CMV infection can reduce EPO synthesis in 
the kidneys [a]. Plasma EPO concentration in anemic CKD and RRT patients is roughly similar as in nonanemic subjects with intact kidney function, but is inappropriately low in the context of the actual blood hemoglobin concentration. Moreover, in CKD patients erythropoietin resistance commonly occurs [1]. Anemia is the direct clinical consequence of EPO deficiency in CKD and RRT patients. Plasma EPO concentration assessment in CKD patients is not used in clinical practice. Decisions concerning treatment with erythropoiesis stimulating agents (ESAs) in CKD and RRT patients are based on the repeated measurement of the blood hemoglobin concentration as well as the patients' clinical status but usually not on plasma EPO concentration.

\section{Abnormalities in the vitamin D metabolites}

In general population, low vitamin D status has been linked to increased occurrence of hypertension, cardiovascular diseases, metabolic syndrome, obesity, insulin resistance and albuminuria. The prevalence of 25-hydroxyvitamin $\mathrm{D}_{3}$ deficiency increases with the progression of CKD and reaches $80 \%$ in patients with CKD stage 5. Additionally, in patients with nephrotic syndrome, the $25(\mathrm{OH}) \mathrm{D}_{3}$ is excessively excreted with the urine. Moreover, in patients treated with peritoneal dialysis vitamin D is washed out with the peritoneal dialysis fluid. The supplementation with ergocalciferol in CKD patients is considered to safe and is recommended in patients with serum $25(\mathrm{OH}) \mathrm{D}_{3}$ concentration below $30 \mathrm{ng} / \mathrm{ml}$.

$25(\mathrm{OH}) \mathrm{D}_{3}$ is further hydroxylated in the kidney, what results in the production of its active metabolite $-1,25(\mathrm{OH})_{2} \mathrm{D}_{3}$. With the decrease of GFR the decline in the activity of $1 \alpha-$ hydroxylase occurs. Moreover, the amount of $25(\mathrm{OH}) \mathrm{D}_{3}$ delivered to the kidney (via receptor mediated mechanism involving megalin) decreases. Additionally, increased plasma concentration of Fibroblast Growth Factor 23 (FGF23) may directly inhibit the abovementioned hydroxylation and promote the synthesis of $24,25(\mathrm{OH})_{2} \mathrm{D}_{3}$, which seems to be metabolically inactive. Thus, in CKD stage 5 patients the plasma $1,25(\mathrm{OH})_{2} \mathrm{D}_{3}$ concentration is decreased. Moreover, a decrease in the density of $1,25(\mathrm{OH})_{2} \mathrm{D}_{3}$ receptors (VDR) in these CKD patients has been described. This leads to the target organ resistance to the $1,25(\mathrm{OH})_{2} \mathrm{D}_{3}$ in this group of patients.
Calcitriol deficiency in patients with CKD plays an important role in the development of secondary hyperparathyroidism, decreased absorption of calcium in the intestine, defective bone mineralization and skeletal resistance to the calcemic action of PTH as well as impaired longitudinal growth in children and myopathy. Some studies suggest that $1,25(\mathrm{OH})_{2} \mathrm{D}_{3}$ deficiency is responsible for the increase in the cardiovascular and general mortality in CKD patients. The results of the small interventional studies suggest that treatment with calcitriol or other VDR agonists may reduce the mortality among these patients. Recent studies showed that $1,25(\mathrm{OH})_{2} \mathrm{D}_{3}$ deficiency increases proteinuria in CKD patients and paricalcitol treatment seemed to ameliorate this pathology. Also, treatment with cinaclalcet may be beneficial in this group of patients, as it decreases plasma FGF23 concentration, what may contribute to the lesser vitamin $\mathrm{D}_{3}$ degradation in these patients and might decrease the cardiovascular risk.

Nevertheless, larger prospective studies are needed to further elucidate the abovementioned relations $[2, \mathrm{~b}]$.

\section{Abnormalities of the hypothalamic- pituitary-gonadal axis in male CKD patients}

CKD is a prominent cause of many derangements of the hypothalamic-pituitary-gonadal axis in males (Table 2), the most of which affect directly the function of gonads.

Table 1

\section{Hypothalamic-pituitary-gonadal axis disturbances in chronic kidney disease}

\begin{tabular}{lcc}
\hline & Female & Male \\
\hline FSH & $\mathrm{N}$ & $\uparrow$ \\
LH & $\uparrow$ & $\uparrow$ \\
Prolactin & $\uparrow$ & $\uparrow$ \\
Estradiol & $\downarrow$ & $\mathrm{N}$ \\
Progesterone & $\downarrow$ & - \\
Testosterone & - & $\downarrow$ \\
\hline
\end{tabular}

FSH - follicle-stimulating hormone; LH - luteinizing hormone; $\mathrm{N}$ - normal.

\section{Follicle-stimulating hormone}

In patients with CKD, serum concentrations of follicle stimulating hormone (FSH) may 
be either elevated, or in the "upper normal" range. FSH is an important factor involved among others in spermatogenesis. It stimulates testicular growth and increases the synthesis of testosterone-binding globulin in the Sertoli cells. In CKD patients, spermatogenesis is usually impaired despite the elevated serum FSH concentrations, what may be caused by the testis resistance to $\mathrm{FSH}$, or due to primary testicular dysfunction [3].

\section{Luteinizing hormone}

In patients with CKD, the lack of appropriate cyclic release of gonadotropin releasing hormone $(\mathrm{GnRH})$ and the decrease amplitudes of the secretory bursts of GnRH by the hypothalamus occurs, what leads to a loss of normal pulsatile release of luteinizing hormone (LH) by the pituitary gland. Among the causes of altered cyclic release of GnRH hyperprolactinemia and high plasma GnRH and LH concentrations may be mentioned. These disturbances are caused mainly by reduced renal clearances of $\mathrm{GnRH}$ and LH [3].

In the majority of $\mathrm{CKD}$ patients, basal plasma LH concentrations are elevated, caused by the decreased catabolism and lack of GnRH inhibition by testosterone (due to lower plasma testosterone concentration in $\mathrm{CKD}$ ).

\section{Prolactin}

In the majority of male hemodialysis patients serum prolactin (PRL) concentrations are elevated. Apart from the increased basal prolactin concentrations, also the daily rhythm of prolactin secretion is altered. Moreover, the sleep-induced secretory bursts of prolactin secretion are rarely observed, although episodic PRL secretion during the daytime occurs.

Probably both the decline of renal prolactin clearance and increased production rate (caused by the inadequate dopaminergic inhibition of prolactin release) contribute to hyperprolactinemia in patients with CKD [4]. Prolactin accumulation causes the inhibition of pulsatile secretion of GnRH as well as the decrement in the testosterone synthesis, which results in worsening of sexual functions and infertility. Interestingly, in some CKD patients, correction of the hyperprolactinemia by bromocriptine with concomitant improvement of sexual function has been described.
The association between hyperprolactinemia and negative cardiovascular outcome was also described in patients with CKD. This relation probably arises from the fact, that increased prolactin concentration may participate in the dysfunction of endothelium. In small clinical study a reduction of blood pressure and hypertrophy of left ventricle was found in patients with CKD after bromocriptine administration [4].

\section{Testicular Hormones}

In the majority of most hemodialysis males serum total and free testosterone concentrations are low, nonetheless the daily circadian rhythm of serum testosterone concentration fluctuations, with a peak at 4 to 8 am and nadir at 8 to $12 \mathrm{pm}$ is usually maintained in CKD patients. It is not yet known whether the decreased serum testosterone concentration is caused by the impaired synthesis, aggravated catabolism, or a combination of both. Additionally, the response to stimulation with human gonadotropin is blunted and delayed.

Malnutrition also take part in the decreesed serum concentrations of testosterone in CKD male patients. In CKD patients on a low-protein diet, essential amino acids and aminoacid ketoanlogues supplementation led to the increase of serum testosterone concentration $[3,5]$. Moreover, the decreased serum concentration of androstenedione and dehydroepiandrostrone sulfate have been reported in male patients with CKD.

The deficiency of androgens in CKD males may be responsible of the changes in body composition. It leads to the increase of adipose tissue content, while the lean body mass (mainly mass of the muscles) is decreases. Androgen deficiency may also lead to the development of the bone disease related to CKD (with the higher incidence of bone fractures), anemia, decreased libido, impairment of sexual function and depression. Finally, the association of low plasma testosterone concentrations with worse outcomes in male hemodialysis patients has been recently described [5].

Testosterone therapy is not exempted from risks, therefore the evidence from large, clinical studies, suggesting benefits of such a treatment, are needed before it could be recommended in CKD patients with hypogonadism $[4,5]$. 


\section{Abnormalities of the hypothalamic- pituitary-gonadal axis in female CKD patients}

Women with CKD also present a variety of derangements of the hypothalamic-pituitarygonadal axis (Table 2). The consequences of which are anovulatory menstrual cycles and thus infertility.

\section{Luteinizing hormone}

In most premenopausal CKD patients serum LH concentration is increased. In healthy premenopausal females secretion of LH occurs in a pulsatile manner. In women with CKD, the disruption cyclic GnRH release in the hypothalamus leads to the loss of appropriate pulsatile release of LH by the pituitary. In healthy females, estradiol feedback blunts the magnitude of LH pulses, while in women with CKD, it fails to diminish the $\mathrm{LH}$ surge, what suggests the feedback is impaired. The aforementioned disturbances lead to the impairment of ovulation what is the direct cause of infertility in women with CKD [6].

\section{Follicle-stimulating hormone}

Conversely to the altered concentrations of serum LH, in the majority of premenopausal women with $\mathrm{CKD}$, the serum concentrations of $\mathrm{FSH}$ are normal, thus the FSH/LH ratio is decreased. This phenomenon seem to contradict the assumption of primary ovarian failure in CKD and suggests that rather the hypothalamic-pituitary axis deregulation occurs [6].

\section{Prolactin}

In women on RRT the serum prolactin concentrations are most often increased and the surge of plasma prolactin after the thyrotropinreleasing hormone (TRH) administration is blunted. In this group of patients amenorrhea is most frequent in patients with high serum prolactin concentration [6].

\section{Estrogens}

In women with $\mathrm{CKD}$, the serum concentrations of estradiol may be either normal, or low and are consistently lower if hyperprolactinemia occurs. In the second half of menstrual cycle, serum progesterone concentrations are decreased due to the defective follicle luteinization. The aforementioned hormonal disturbances are the consequence of derangements of regulation at the hypothalamus level [6].
One of the most important consequences of the low plasma estrogens concentration is bone disease [7]. Women with amenorrhea not only have decreased serum estrogens concentrations, but also lower mineral bone density in comparison with the regularly menstruating female dialysis patients. The results of small interventional studies suggest that treatment with transdermal estradiol, or treatment with a selective estrogen receptor modulator (SERM) - raloxifene may increase bone mineral density in postmenopausal females on hemodialysis. However it must be emphasized (especially in the light of the potential cardiovascular adverse effects), that currently long-term studies safety of hormone replacement, or SERM therapy in women with CKD are not available

\section{Abnormalities in the growth Hormone-insulin like growth factor (somatotropic) axis}

Several hormones and growth factors are involved in the appropriate function of the somatotropic axis in human. The list of the most important comprises of e.g. growth hormone $(\mathrm{GH})$, insulin-like growth factor 1 and 2 (IGF-1 and -2), IGF binding proteins (IGFBP) and the IGFBP proteases. Physiological function of the proteins mentioned above is the modulation of somatic growth and cellular proliferation.

The disruptions of the somatotropic axis have been reported in children, as well as in adults with CKD and may have substantial clinical consequences. In children the most severe is the growth retardation with decreased final adult height. It is of note, that growth impairment in patients with CKD is associated with increased morbidity and mortality $[8,9]$.

\section{Growth hormone}

Generally, in children and adult CKD patients, serum GH concentration is normal or elevated depending on the extent of the GFR impairment [10], what is caused by a reduction of the renal hormone's clearance with the concomitant increase of GH secretion. Hyperglycemia induced by glucose infusion suppresses $\mathrm{GH}$ secretion in individuals with no kidney disease, but fails to do so in CKD patients. Moreover, in $\mathrm{CKD}$ the exaggerated $\mathrm{GH}$ secretion rate after the stimulation with exogenous GHRH occurs.

All of the alterations mentioned above have led to the theory of $\mathrm{GH}$ resistance or in- 
sensitivity in patients with terminal CKD. This may be caused by the decreased density of GH receptors in the target organs, as the serum growth hormone binding protein (GHBP) concentration (which is a cleaved product of the $\mathrm{GH}$ receptor and may be used to assess $\mathrm{GH}$ receptor density in different organs) is decreased in children and adults with CKD proportionally to the decrease in glomerular filtration.

Additionally, evidences exist suggesting that in uremia $\mathrm{GH}$ resistance may be also postreceptor level with the alteration of intracellular signal transduction. This is due to the defect in the GH activated JAK2 and STAT signal transduction caused by the impaired phosphorrylation and nuclear translocation of the cascade of STAT proteins [10]. Also the increased expression of suppressor of cytokine signaling (SOCS2 and SOCS3) genes may lead to the suppression in the GH signal transduction [12].

Among other factors contributing to the $\mathrm{GH}$ resistance in CKD: metabolic acidosis, inflammation and hyperparathyroidism can be reckoned.

\section{Insulin-like growth factors}

Contrary to the traditional views the influence of GH in the promotion of linear growth is not only caused by the GH related stimulation of IGF-1 synthesis in the liver, which then reaches the bones' growth plate to stimulate growth. It has been recently shown that not all of the effects of $\mathrm{GH}$ are mediated by IGF-1.

IGF-1 and IGF-2 can be locally synthesized locally by most tissues, (including the bones' growth plate). Nevertheless, liver slays the main source of circulating IGF-1.

The most of IGF-1 circulates in serum as a $150 \mathrm{kDa}$ complex with IGF Binding protein-3 (IGFBP3) and the acid lable subunit (ALS), although IGF-1 can also form complexes with other IGF-binding proteins (IGFBP-1 to 6).

Concentration of IGF-1 (the most important factor in the rapid growth during the puberty period) tends to be normal in pre-terminal kidney disease (CKD 1-4).

Serum free IGF-1 concentration decreeses with the stages of CKD. In CKD 5 such a decrease is mostly due to the elevated concentrations of IGF-binding proteins $-1,-2,-4$, and -6 what results in the diminished pool of free IGF-1. Also, the decreased bioavailability of IGF-1 in the target organs as a result of increased proteolysis of IGFBP-3 has been reported.

Additionally, a small (1 kDa weight) IGF-1 inhibitor has been identified in the sera of patients with CKD, but the detailed structure of this particle has not yet been characterized.

Finally, the resistance to IGF-1 in CKD is also caused by the defect in intracellular signal transduction as both: the autophosphorylation of the IGF-1 receptor tyrosine kinase and susceptibility of the IGF-1R tyrosine kinase to the exogenous insulin receptor substrate-1 (IRS-1) are diminished in CKD $[8,9,11,12]$.

Serum concentration of IGF-2 is in the normal range in pre-terminal kidney disease and increased in CKD stage 5.

\section{Growth hormone therapy}

In spite of the normal or incresed serum $\mathrm{GH}$ concentrations the aforementioned target organ resistance/insensitivity to $\mathrm{GH}$ gives the rationale for the exogenous recombinant human $\mathrm{GH}(\mathrm{rhGH})$ treatment children with growth retardation caused by CKD. Such treatment was found to be both efficacious and safe and resulted in a catch-up growth. $65 \%$ of children treated with rhGH may reach almost normal height in the adulthood [13]. The best response to rhGH treatment was found in patients in predialysis stages of CKD, probably due to better GH sensitivity [14]. The treatment with rhGH has been proven to be also effective in treatment of growth retardation (caused mainly by the glucocorticoid administration) in children after kidney transplantation.

Despite clear benefits (e.g. promoting muscle mass gain and decreasing the protein energy wasting $[8,9,11,12]) \mathrm{rhGH}$ administration in adult CKD patients is not exempted from risks. Clinical studies proving the safety and efficacy of rhGH treatment in CKD patients need to be conducted, before the safe recommendation of such therapy in this group of patients.

\section{Abnormalities in the thyroid gland and hypothalamic-pituitary-thyroid axis}

Abnormalities in both the thyroid gland's function and structure (increased volume of the thyroid gland and higher prevalence of goiter) are common in CKD patients [15]. Uremia affects the hypothalamus-pituitary-thyroid axis, as well as the peripheral metabolism of thyroid 
hormones, thus serum concentrations of thyroid hormones are commonly not normal in CKD patients [15]. The differences in the thyroid hormones' profile alterations in CKD and primary hypothyroidism and chronic non-thyroid, non-kidney illness are presented in Table 3 [16].

Table 2

Hypothalamic-pituitary-thyroid axis alterations in chronic kidney disease, chronic nonthyroidal, nonkidney illness and primary hypothyroidism

\begin{tabular}{lcccc}
\hline & TSH & $\mathbf{T}_{\mathbf{4}}$ & $\mathbf{T}_{\mathbf{3}}$ & $\mathbf{r T}_{\mathbf{3}}$ \\
\hline Chronic kidney disease & $\mathrm{N}$ & $\mathrm{N}, \downarrow$ & $\downarrow$ & $\mathrm{N}$ \\
Chronic nonthyroidal, nonkidney illness & $\mathrm{N}$ & $\mathrm{N}, \downarrow$ & $\downarrow$ & $\uparrow$ \\
Primary hypothyroidism & $\uparrow$ & $\downarrow$ & $\downarrow$ & $\mathrm{N}$ \\
\hline
\end{tabular}

$\mathrm{N}$ - normal; TSH - thyroid-stimulating hormone; T4 - thyroxin; $\mathrm{T} 3$ - triiodothyronine; $\mathrm{rT}_{3}$ - reverse triiodothyronine

\section{Thyroid hormones}

In patients with CKD the serum concentration of thyroxin $\left(\mathrm{T}_{4}\right)$ is usually normal and serum triiodothyronine $\left(\mathrm{T}_{3}\right)$ concentration may be either normal, or reduced. Low $\mathrm{T}_{3}$ syndrome is the most common disturbance in CKD patients, while subclinical hypothyroidism is the most common thyroid disorder found in this group of patients $[17,18]$.

The reduction of serum $\mathrm{T}_{3}$ concentration in CKD patients is a result of the impaired conversion of $\mathrm{T}_{4}$ to $\mathrm{T}_{3}$ caused by the of iodothyronine deiodinase as a result of malnutrition and/or chronic metabolic acidosis. Moreover, the decrease in peripheral conversion of $\mathrm{T}_{4}$ to $\mathrm{T}_{3}$ caused by the reduced clearance of inflammatory cytokines such as TNF-a and IL-6 has been described in CKD [17, 18].

Although $T_{3}$ is the most active of thyroid hormones, CKD patients with low serum $\mathrm{T}_{3}$ concentrations usually appear clinically euthyroid, probably because the expression of messenger RNA for c-erb-A $\alpha$ and $\beta T_{3}$ receptors in the mononuclear cells is increased.

In spite of the decreased renal clearance of $\mathrm{rT}_{3}$ serum concentrations of this hormone in CKD patients are normal. This is in contrast with chronic non-thyroid diseases and is probably caused by the increased cellular uptake of $\mathrm{rT}_{3}$ and also the redistribution of $\mathrm{rT}_{3}$ from the vascular to extravascular space and. Conversely, serum free-r $\mathrm{T}_{3}$ concentrations are elevated in $\mathrm{CKD}$ what is a result of reduced renal clearance.

Importantly the decreased concentrations of thyroid hormones, which are often seen in patients with CKD, may not necessarily be the indicator of thyroid dysfunction. These alterations may be a mere reflection of the chronic illness and/or malnutrition. Traditionally Low $\mathrm{T}_{3}$ status of CKD was viewed as an adaptation, promoting energy saving beneficial in the uremic wasting. Nonetheless, low serum $\mathrm{T}_{3}$ concentration in CKD patients is connected with the endothelial dysfunction, atherosclerosis and cardiac abnormalities. Moreover, low serum free$\mathrm{T}_{3}$ has been linked with the increased cardiovascular mortality in hemodialysed patients [19].

Levothyroxine treatment is not exempted from risks (among them negative protein balance caused by the increased muscle catabolism). There is a need of further clinical studies with clear evidence of benefits of such a therapy in CKD subjects before levothyroxine supplementation can be recommended in these patients $[18,11]$.

\section{The thyroid-stimulating hormone}

Serum concentrations of thyroid-stimulating hormone (TSH) are usually normal in CKD patients even despite a tendency to low serum $\mathrm{T}_{4}$ and $\mathrm{T}_{3}$ concentrations. This discrepancy seems to suggest the deregulation of hypothalamic-pituitary-thyroid axis.

In CKD patients the pituitary receptor response to TRH is blunted what causes a decrease in the production of TSH. Moreover, the response in TSH release after stimulation with TRH is sluggish because of the impaired renal clearance and prolonged half-life of TSH. Also the normal daily rhythm of TSH relaese with a peak in the late evening or early morning is diminished and the nocturnal TSH surge is reduced $[16,18]$. 
Primary hypothyroidism

and hyperthyroidism

Increased prevalence of both overt and subclinical hypothyroidism in CKD patients has been described. Nonetheless, the diagnosis of hypothyroidism in this group of patients raises many significant difficulties because the typical signs and symptoms of hypothyroidism, such as hypothermia, pallor, and asthenia, are also common in the clinical picture of advanced CKD. This is why the diagnosis of primary hypothyroidism in patients with CKD should only be considered if the coexistence of elevated serum TSH concentration and clearly low serum $\mathrm{T}_{4}$ concentrations occurs.

CKD is associated with the decreased iodide excretion, what causes the elevation of serum inorganic iodide concentration and the increased content of iodide in the thyroid gland. The former causes enlargement of the thyroid gland and contributes to the increased prevalence of goiter in CKD. Additionally, the excess of iodide in the thyroid gland may contribute to hypothyroidism through the prolonged WolffChaikoff effect.

In chronic hemodialysis patients a transient increase of serum $\mathrm{T}_{4}$ concentration, caused by using heparin as an anticoagulant, occurs. Heparin competes with $\mathrm{T}_{4}$ at the binding site of the hormone-binding protein, what leads to an increase of serum $\mathrm{T}_{4}$ concentrations for at least 24 hours, thus the blood samples for the assessment of serum thyroid hormones concentration should be collected before heparin administration, which is before the dialysis session.

Among the clinical consequences of hypothyroidism in CKD anemia, muscle wasting, and depression can be reckoned. It is of note that the decreased concentrations of $\mathrm{T}_{3}$ are the independent predictor of cardiovascular and allcause mortality in patients with CKD $[16,20]$.

The prevalence of hyperthyroidism in CKD patients is similar as in the general population. Nevertheless it should be remembered that some aspects of hyperparathyroidism can indeed accelerate the progression of CKD i.e. increased renal blood flow that causes the increase of filtration pressure with glomerular hyperfiltration and increased free radicals generation (caused by the decreased activity of superoxide dismutase).
Abnormalities in insulin and glucagon

Diverse alterations in the insulin-glucose environment are seen in patients with CKD what contributes to the disrupted carbohydrate metabolism $[22,23]$.

\section{Insulin secretion and clearance}

Insulin secretion is impaired in CKD what is caused by, among others, high serum PTH and low serum plasma $1,25(\mathrm{OH})_{2} \mathrm{D}_{3}$ concentrations.

The kidney is an important organ in the insulin metabolism. Insulin is filtered in the glomeruli and then reabsorbed in the proximal tubule. In apparently healthy subjects renal clearance of insulin is roughly $200 \mathrm{~mL} /$ minute what exceeds the glomerular filtration rate (GFR), indicating also peritubular uptake of insulin takes place. It is estimated that 6-8 units of insulin are removed daily by the kidney, what is $25-40 \%$ of the total removal of endogenous insulin. CKD patients develop a decrease in the metabolic clearance of insulin when GFR falls below $40 \mathrm{ml} / \mathrm{minute}$. This causes fasting hyperinsulinemia and accounts for decreased insulin requirement in diabetic patients with CKD [22].

\section{Insulin Resistance}

Peripheral resistance to insulin is seen early in the course of CKD. Mostly the skeletal muscles develop decreased insulin sensitivity and higher serum insulin concentrations are required to increase glucose uptake by skeletal muscle. It needs to be stressed that the defect does not only concern the insulin receptor, but presumably also takes place at the postreceptor level, as the impairment of phosphatidyl-inositol 3-kinase activity (PI3-K) was documented in CKD patients.

As it was mentioned above insulin resistance occurs early in CKD and tends to aggravate with the CKD stages. It is thus found in the majority of patients with advanced CKD. After initiating RRT peripheral insulin resistance markedly decreases, however only after several weeks of treatment. Presumably, an unidentified dialyzable uremic "toxins" are involved in the pathogenesis of improper insulin activity in target organs. Such compounds with a molecular weight of 1 to $2 \mathrm{kDa}$ are specific for CKD - they are not found in nonuremic patients with insulin resistance.

Some of the factors involved in insulin resistance in CKD are generally modifiable. 
For example in HD patients, insulin resistance is ameliorated by treatment with erythropoietin or $1,25(\mathrm{OH})_{2} \mathrm{D}_{3}$ and in predialysis patients can be ameliorated by dietary protein restriction.

Also the serum concentrations of insulin antagonists: glucagon and growth hormone are frequently increased in CKD patients. It has been postulated that these two hormones, as well as metabolic acidosis, chronic inflamemation and increased activity of renin-angiotensin system activity may also participate in the pathogenesis of insulin resistance in CKD patients [23].

Clinical consequences of hyperglycemia and insulin resistance

Both the hyperglycemia and insulin resistance in patients with CKD have been shown to increase cardiovascular risk and CKD progression and contribute to the development of hypertension due to the higher salt sensitivity cause by the increased tubular sodium reabsorption. Insulin resistance may also participate in the development of malnutrition often found in this group of patients and as it stimulates the muscle catabolism through the activation of a common proteolytic pathway via the ubiquitin-proteasome system $[22,23]$.

\section{Abnormalities in the hormones of adipose tissue}

The adipose tissue can be perceived as an endocrine organ as it produces a variety of biologically active substances (adipokines). The increase of plasma concentrations of different adipokines are found in CKD patients. The most important adipokines, of proven systemic activity are among others: leptin adiponectin, resistin and visfatin [24].

Plasma leptin concentration is increased in patients with CKD as its clearance is decreesed in the failing kidney. Leptin is a factor stimulating the proliferation and differentiation of hematopoietic stem cells. It is likely that the effects of leptin and erythropoietin are synergistic. Furthermore, hyperleptinemia stimulates the activity of the sympathetic nervous system and is therefore involved in the in progression of CKD, pathogenesis of hypertension and cardiovascular diseases [24].

Plasma concentration of adiponectin is also elevated in patients with CKD what is caused by the disturbances of its biodegradation and elimination by the failing kidneys. Clinical consequences of increased plasma adiponectin concentration in CKD are not clear [24]. Nonetheless it seems that in CKD patients the unique anti-atherosclerotic activity of adiponectin is diminished due to the resistance at a receptor level.

Plasma concentration of resistin is increased in CKD patients, mainly due to its reduced renal clearance. Resistin, at concentrations typical for CKD patients inhibits neutrophil activity. It may thus be one of prominent causes of the increased prevalence of infections in CKD patients. Moreover, resistin appears to have a role in the pathogenesis of cardiovascular disease in CKD patients as chronic hemodialysis patients with low serum resistin concentration are characterized by a poor hospitalization-free survival [24].

Plasma concentration of visfatin gradually increases with the decrease of GFR and is positively correlated with endothelial dysfunction. This adipokine stimulates monocyte adhesion to the endothelial cells. Visfatin also may be involved in the pathogenesis of malnutrition in CKD. Additionally, high plasma visfatin concentration predicted mortality in CKD patients [24].

\section{REFERENCES}

1. Fisher JW. Erythropoietin: physiology and pharmacology update. Exp Biol Med (Maywood). 2003; 228: $1-14$

2. Dusso A, González EA, Martin KJ. Vitamin D in chronic kidney disease. Best Pract Res Clin Endocrinol Metab. 2011; 25: 647-55.

3. Iglesias P, Carrero JJ, Díez JJ. Gonadal dysfunction in men with chronic kidney disease: clinical features, prognostic implications and therapeutic options. J Nephrol. 2012; 25: 31-42.

4. Ros S, Carrero JJ. Endocrine alterations and cardiovascular risk in CKD: Is there a link? Nefrologia. 2013; 33: 181-87.

5. Carrero JJ, Stenvinkel P. The vulnerable man: impact of testosterone deficiency on the uraemic phenotype. Nephrol Dial Transplant. 2012; 27: 4030-41.

6. Holley JL. The hypothalamic-pituitary axis in men and women with chronic kidney disease. Adv Chronic Kidney Dis. 2004; 11: 337-41.

7. Sugiya N, Nakashima A, Takasugi N, et al. Endogenous estrogen may prevent bone loss in postmenopausal hemodialysis patients throughout life. Osteoporos Int. 2011; 22: 1573-9.

8. Mak RH, Cheung WW, Roberts CT Jr. The growth hormone-insulin-like growth factor-I axis in chronic 
kidney disease. Growth Horm IGF Res. 2008; 18 : 17-25.

9. Gupta D, Gardner M, Whaley-Connell A. Role of growth hormone deficiency and treatment in chronic kidney disease. Cardiorenal Med. 2011; 1: 174-82.

10. Wiezel D, Assadi MH, Landau D, Troib A, Kachko L, Rabkin R, Segev Y. Impaired renal growth hormone JAK/STAT5 signaling in chronic kidney disease. Nephrol Dial Transplant. 2014; 29: 791-9.

11. Mahesh S, Kaskel F. Growth hormone axis in chronic kidney disease. Pediatr Nephrol. 2008; 23: 41-8.

12. Salas P, Pinto V, Rodriguez J, Zambrano MJ, Mericq V. Growth retardation in children with kidney disease. Int J Endocrinol. 2013; doi: 10.1155/2013/970946

13. Haffner D, Schaefer F, Nissel R, Wühl E, Tönshoff $\mathrm{B}$, Mehls O. Effect of growth hormone treatment on the adult height of children with chronic renal failure. German Study Group for Growth Hormone Treatment in Chronic Renal Failure. N Engl J Med. 2000; 343: 923-30.

14. Mehls O, Lindberg A, Nissel R, Haffner D, HokkenKoelega A, Ranke MB. Predicting the response to growth hormone treatment in short children with chronic kidney disease. J Clin Endocrinol Metab. 2010; 95: 686-92

15. Iglesias P, Díez JJ. Thyroid dysfunction and kidney disease. Eur J Endocrinol. 2009; 160: 503-15.

16. Abdel-Rahman EM, Mansour W, Holley JL. Thyroid hormone abnormalities and frailty in elderly patients with chronic kidney disease: a hypothesis. Semin Dial. 2010; 23: 317-23.

17. Basu G, Mohapatra A. Interactions between thyroid disorders and kidney disease. Indian J Endocrinol Metab. 2012; 16: 204-13.

18. Mohamedali M, Reddy Maddika S, Vyas A, Iyer V, Cheriyath P. Thyroid disorders and chronic kidney disease. Int J Nephrol. 2014; doi: 10.1155/2014/520281.

19. Xu G, Yan W, Li J. An update for the controversies and hypotheses of regulating nonthyroidal illness syndrome in chronic kidney diseases. Clin Exp Nephrol. 2014; 18: 837-43.

20. Zoccali C, Mallamaci F, Tripepi G, Cutrupi S, Pizzini $\mathrm{P}$. Low triiodothyronine and survival in endstage renal disease. Kidney Int. 2006; 70: 523-8

21. Lu Y, Ku E, Campese VM, Aldosterone in the pathogenesis of chronic kidney disease and proteinuria. Curr Hypertens Rep. 2010; 12: 303-6.
22. Liao MT, Sung CC, Hung KC, Wu CC, Lo L, Lu $\mathrm{KC}$. Insulin resistance in patients with chronic kidney disease. J Biomed Biotechnol. 2012; 2012: 691369.

23. Siew ED, Ikizler TA. Insulin resistance and protein energy metabolism in patients with advanced chronic kidney disease. Semin Dial. 2010; 23: 378-82.

24. Adamczak M, Wiecek A. The adipose tissue as an endocrine organ. Semin Nephrol. 2013; 33: 2-13.

Резиме

\section{ЕНДОКРИНИ АБНОРМАЛНОСТИ КАЈ ПАЦИЕНТИ СО ХРОНИЧНА БУБРЕЖНА БОЛЕСТ}

\section{Пјотр Кучера, Марцин Адамчак, Анджеј Вичек}

Оддел за нефрологија, трансплантација

и интерна медицина, Медицински универзитет на Шлезија, Катовице, Полска

Кај пациенти со хронична бубрежна болест промените во ендокриниот систем можат да се јават од неколку причини. Бубрегот е место на деградација, како и на синтеза на многу различни хормони. Покрај тоа, голем број придружни патолошки состојби, како што се различни воспаленија, метаболна ацидоза и неисхранетост, може да учествуваат во патогенезата на ендокрините абнормалности кај оваа група пациенти. Најизразени ендокрини абнормалности кај пациентите со хронична бубрежна болест се недостатоци на: калцитриол, тестостерон, фактор на раст сличен на инсулин и еритропоетин (ЕПО). Дополнителното акумулирање на неколку хормони, како што се: пролактин, хормон за раст и инсулин, исто така, се случува доста често. Клиничките последици од гореспоменатите ендокрини абнормалности, меѓу другите, се: анемија, неплодност и заболување на коските.

Клучни зборови: хронична бубрежна болест, ендокрини абнормалности, еритропоетин 